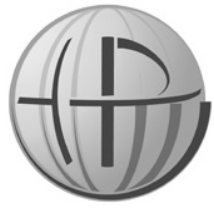

Horyzonty Polityki 2021, Vol. 12, No 40

\section{Wiktor Możgin}

http://orcid.org/0000-0001-5744-8103 Uniwersytet Jagielloński w Krakowie Instytut Studiów Międzykulturowych wiktor.mozgin@gmail.com

DOI: $10.35765 / H P .2126$

\title{
Deoligarchizacja na Ukrainie. Czy istnieje szansa na naprawę ukraińskiego systemu politycznego?
}

\section{Streszczenie}

CEL NAUKOWY: Celem artykułu jest analiza zjawiska deoligarchizacji na Ukrainie uwzględniająca okres prezydentury Petra Poroszenki oraz Wołodymyra Zełenskiego.

PROBLEM I METODY BADAWCZE: Zasadniczym problemem badawczym jest wskazanie, czy po rewolucji godności jest możliwa transformacja systemowa zmierzająca do zminimalizowania wpływów oligarchów na życie polityczne i gospodarcze na Ukrainie? W tym celu autor wykorzystuje metodę porównawczą uwzględniającą badanie konkretnych zdarzeń i zjawisk. Ponadto wykorzystano również metodę otwartych wywiadów z ukraińskimi ekspertami, aby zwiększyć w ten sposób obiektywizm prezentowanych wyników analizy.

PROCES WYWODU: Proces wywodu polega na analizie warunków, w jakich kształtował się ukraiński model demokracji oligarchicznej po 1991 roku. Drugim stopniem analizy jest porównanie sposobów walki z systemem oligarchicznym na Ukrainie podejmowanych po rewolucji godności przez Petra Poroszenkę oraz Wołodymyra Zełenskiego.

WYNIKI ANALIZY NAUKOWEJ: Konkluzją artykułu jest twierdzenie, iż społeczeństwo ukraińskie po rewolucji godności domagało się zminimalizowania oligarchicznych wpływów na życie polityczne i gospodarcze w państwie. Zdaniem autora Petro Poroszenko, będący "starym” graczem na ukraińskiej scenie politycznej, utrzymał istniejący układ wzajemnych korzyści na linii władza-oligarchowie. Z kolei przyjście do władzy Wołodymyra Zełenskiego, 
uważanego za „nowego”, antysystemowego kandydata, zapoczątkowało zmianę tego modelu i naprawę systemu demokratycznego w państwie.

WNIOSKI, INNOWACJE, REKOMENDACJE: Autor dochodzi do wniosku, że realizacja planu deoligarchizacji na Ukrainie w okresie prezydentury Petra Poroszenki była przede wszystkim przejawem ukrytej wojny tego polityka z konkretnymi oligarchami. Celem tego było zbudowanie silnej własnej pozycji w państwie. Z kolei Wołodymyr Zełenski, mimo wielu zarzutów kooperacji w oligarchami, rozpoczął realizację kompleksowej walki z destrukcyjnym oligarchicznym systemem, co stanowi precedens w tym zakresie na Ukrainie. Wskutek realizacji polityki deoligarchizacyjnej w państwie ukraińskim zaczyna kształtować się nowy model relacji na linii władza-oligarchowie. Stanowi to novum, które może być wykorzystane jako punkt odniesienia dla kolejnych badań nad kwestią systemowej transformacji Ukrainy, realizowanych zarówno w Polsce, jak i innych krajach.

\title{
SŁowA KLUCzowe:
}

Ukraina, system polityczny, transformacja ustrojowa, demokracja oligarchiczna, deoligarchizacja

\author{
Abstract \\ DE-OLIGARCHIZATION IN UKRAINE. \\ IS THERE A CHANCE TO REPAIR \\ THE UKRAINIAN POLITICAL SYSTEM?
}

RESEARCH OBJECTIVE: The aim of the article is to analyze the de-oligarchization phenomenon in Ukraine, taking into account the presidencies of Petro Poroshenko and Volodymyr Zelensky.

THE RESEARCH PROBLEM AND METHODS: The main research problem is to indicate whether a systemic transformation aimed at minimizing the influence of the oligarchs on political and economic life in Ukraine is possible after the Revolution of Dignity? For this purpose, the author uses a comparative method that includes the study of specific events and phenomena.

THE PROCESS OF ARGUMENTATION: The process of argumentation consists in analyzing the conditions in which the Ukrainian model of oligarchic democracy was shaped after 1991. The second stage of the analysis is to compare the methods of fighting against the oligarchic system in Ukraine undertaken by Petro Poroshenko and Volodymyr Zelensky after the revolution of dignity. 
RESEARCH RESULTS: The article concludes that after the Revolution of Dignity, Ukrainian society demanded that the oligarchic influence on political and economic life in the state be minimized. According to the author, Petro Poroshenko, who is an "old" player on the Ukrainian political scene, maintained the existing system of mutual benefits between the government and the oligarchs. In turn, the coming to power of Volodymyr Zelensky, who is considered a "new", anti-system candidate, initiated a change in this model and the repair of the democratic system in the state.

CONCLUSIONS, INNOVATIONS AND RECOMMENDATIONS: The author concludes that the implementation of the de-oligarchization plan in Ukraine during the presidency of Petro Poroshenko was primarily a manifestation of this politician's hidden war with specific oligarchs. In turn, Volodymyr Zelensky, despite numerous accusations of cooperation with the oligarchs, has started a comprehensive fight against the destructive oligarchic system, which is a precedent in this respect in Ukraine. As a result of the implementation of the de-oligarchization policy in the Ukrainian state, a new model of relations between the government and the oligarchs is beginning to take shape. This is a novelty that can be used as a reference point for further research on the issue of systemic transformation in Ukraine.

\section{KeYwORDS:}

Ukraine, political system, systemic transformation, oligarchic democracy, de-oligarchization

\section{WPROWADZENIE}

Zgodnie z corocznym raportem Democracy Index, publikowanym przez The Economist Intelligence Unit, Ukraina w 2020 roku zajmowała 79. pozycję, znajdując się wśród państw z hybrydowym systemem politycznym (The Economist Intelligence Unit, et al., 2021). Należy przez to rozumieć niepełną transformację systemową państwa z modelu autorytarnego do demokratycznego. W przypadku Ukrainy proces ten powinien podążać zgodnie $\mathrm{z}$ ustalonym w momencie uzyskania przez to państwo niepodległości wektorem i jednocześnie obejmować kilka zasadniczych etapów - przejście od gospodarki planowej do rynkowej, transformację instytucjonalno-prawną oraz zmianę rządzącej elity w wyniku demokratycznych wyborów. Tym czasem okazało się, że rzeczywistość jest o wiele bardziej złożona i nieprzewidywalna, bowiem cele narzucone Ukrainie przez zachodnie demokracje były nieadekwatne w stosunku do 
oczekiwań rządzących, którzy przejęli stery władzy w tym państwie po rozpadzie Związku Radzieckiego. W tym zakresie proces transformacji ustrojowej sprowadzono do „uprzedmiotowienia” państwa służącego bogaceniu się niewielkiej grupy osób. W szczególny sposób było to zauważalne w kontekście realizacji planów prywatyzacji państwowych przedsiębiorstw. W latach 1994-2003 państwo ukraińskie przeżyło nie „szokową terapię gospodarczą" a "gospodarczy szok", spowodowany masową upadłością przedsiębiorstw państwowych. Apogeum tego procesu miało miejsce $\mathrm{w}$ drugiej połowie lat 90., bowiem w 1994 roku zbankrutowały 194 przedsiębiorstwa, w 1995 2000, w 1996 roku - 2800, z kolei w roku 1997 ich liczba sięgnęła aż 6700 (Biryukov, 2001). Doprowadzone do upadłości przedsiębiorstwa były następnie za bezcen kupowane przez przedstawicieli nowo powstałej warstwy najbogatszych osób w państwie. Nabywanie w ten sposób większościowych udziałów akcyjnych w spółkach państwa przerodziło się $\mathrm{w}$ stałą praktykę. Zgodnie $\mathrm{z}$ wyliczeniami ukraińskich analityków do 2001 roku tą drogą sprywatyzowano aż 58\% przedsiębiorstw $^{1}$ (Larcev, Klyuchnikov, 2001). Tego typu procesy prywatyzacyjne były możliwe jedynie wskutek braku w państwie niezbędnych mechanizmów regulujących rynek oraz przepływ środków finansowych (Holovko, 2012). W rezultacie doprowadziło to do powstania finansowo-przemysłowych grup oraz ukształtowania się specyficznego oligarchicznego modelu państwa, polegającego na symbiozie władzy i biznesu.

W tym miejscu warto podkreślić znaczenie osoby prezydenta. Od 1994 roku, czyli od momentu objęcia władzy przez Leonida Kuczmę, na Ukrainie zaczęła się kształtować wertykalna zależność polityków oraz oligarchów od głowy państwa. Leonid Kuczma, poprzez umiejętne wykorzystywanie swojej pozycji, sprzyjał poszerzaniu wpływów oligarchów na życie politycznie i gospodarcze w państwie, jednocześnie występując $\mathrm{w}$ roli arbitra utrzymującego równowagę między ich zapędami. W okresie prezydentury Leonida Kuczmy wykreowano tzw. „oligarchiczny konsensus”. Przejawiał się on przede

1 Słynna stała się sprawa prywatyzacji państwowego mienia z 2011-2012, kiedy aukcje 6 najważniejszych spółek energetycznych sprzedano koncernowi Ukrainie System Capital Management (SCM) w cenie jedynie trzykrotnie przewyższającej wartość londyńskiego mieszkania Rinata Achmetowa, właściciela SCM. 
wszystkim w rozłożeniu politycznych wpływów oligarchów, bowiem ten, kto miał „układ” z prezydentem, miał większe możliwości. W ten sposób na Ukrainie zaczął się kształtować, w sensie politycznym, "system quasi-autorytarny", w którym prezydent decydował o wszystkim, co się dzieje w państwie.

Aspekty te dzisiaj nadal są aktualne i stanowią jedne z najważniejszych problemów państwa w kontekście transformacji ustrojowej. Mimo wyrażanych podczas rewolucji godności postulatów deoligarchizacji państwowej przestrzeni, Ukraina podąża w kierunku zachodnich demokracji, nadal niosąc brzemię państwa oligarchicznego. Paradoksem jednak jest to, że w państwie, w którym istnieją i są skutecznie wykorzystywane demokratyczne mechanizmy przejęcia władzy, każdorazowo jest zawierany konsensus na linii rządzący oligarchowie, który sprzyja dalszemu utrzymaniu państwa ukraińskiego w rękach wąskiej grupy najbogatszych osób, skupiających siły jedynie na realizacji swoich partykularnych interesów. Niewątpliwie ma to negatywne skutki dla rozwoju państwa, bowiem wpływa między innymi na postępującą gospodarczo degradację oraz rażącą ekonomiczną stratyfikację społeczną.

Demokracja oligarchiczna w wydaniu ukraińskim ma wyjątkowy charakter, co stanowi niezwykle interesujący przedmiot badawczy. Sławomir Matuszak w tekście zatytułowanym Demokracja oligarchiczna. Wptyw grup biznesowych na ukrainska polityke (2012) przedstawił rzetelną i kompleksową analizę tego zjawiska, dochodząc do ogólnego wniosku, że oligarchiczny system panujący na Ukrainie hamuje rozwój kraju zarówno pod względem politycznym, jak i gospodarczym (Matuszak, 2012). Rzecz jasna, praca ta nie jest wyjątkiem, lecz warto podkreślić, że w Polsce w ostatnim czasie tematyka dotycząca ukraińskiej oligarchii nie była szeroko omawiana, zwłaszcza biorąc pod uwage analizę modelu demokracji oligarchicznej w tym państwie. Kwestię oligarchii i jej wpływu na współczesną ukraińską politykę oraz gospodarkę zasadniczo podejmowano w kontekście innych ważnych wydarzeń. Analizowano bowiem wpływy oligarchów na przebieg rewolucji godności, czy też ich znaczenie w początkowych stadiach rosyjskiej agresji na Ukrainę ${ }^{2}$ oraz kalkulowano

2 Wiosną 2014 roku, tuż po aneksji Półwyspu Krymskiego, część oligarchów przejęła kontrolę nad wybranymi regionami Ukrainy. Doskonałym 
straty i zyski najbogatszych osób w państwie w kontekście trwającej po dziś dzień wojny w Donbasie. Tym niemniej zasadne wydaje się spojrzenie na problematykę oligarchii w państwie ukraińskim $\mathrm{z}$ nieco innej perspektywy. Warto poddać analizie proces walki z tym zjawiskiem implementowanym $\mathrm{w}$ ukraiński system polityczny po wydarzeniach rewolucji godności przez prezydentów tego państwa Petra Poroszenkę oraz Wołodymyra Zełenskiego. Uzasadnione jest podkreślenie, że autor dokonuje analizy porównawczej procesów deoligarchizacyjnych w dwóch różnych, pod względem czasowym, okresach. Prezydentura Petra Poroszenki stanowi zamknięty okres badawczy, inaczej niż Wołodymyra Zełenskiego - nadal trwający, co pozwala na analizę jedynie niektórych zachodzących w trakcie jego prezydentury procesów oraz zjawisk. Tym niemniej, autor wskazuje, iż zasadność napisania niniejszego artykułu jest podyktowana przyjęciem w czerwcu 2021 roku z inicjatywy Wołodymyra Zełenskiego ustawy deoligarchizacyjnej, stanowiącej precedens $w$ historii państwa ukraińskiego, bowiem dotychczas żaden z przywódców tego państwa nie podjął na taką skalę formalnych i systemowych rozwiązań walki ze zjawiskiem oligarchii. Artykuł ten zapoczątkowuje jednocześnie merytoryczną dyskusję nad kwestią deoligarchizacji na Ukrainie po rewolucji godności. W sytuacji, kiedy dojdzie do zmiany prezydenta w tym państwie, niniejsze rozważania będą stanowiły tło do dalszych rozważań, umożliwiających pełną analizę porównawczą walki z oligarchią na Ukrainie w okresie prezydentur Petra Poroszenki oraz Wołodymyra Zełenskiego.

Deoligarchizacja stanowiła jeden z kluczowych punktów w programach wyborczych obydwu polityków. Istotne jest więc postawienie zasadniczego pytania: $\mathrm{z}$ jakim skutkiem były realizowane obietnice zarówno Petra Poroszenki, jak i Wołodymyra Zełenskiego

przykładem w tym kontekście jest działalność Ihora Kołomojskiego, ówczesnego gubernatora obwodu dniepropietrowskiego. Ten oligarcha sfinansował powstanie ochotniczych grup obronnych, które zwalczały zwolenników separatystycznego ruchu, zapobiegając tym samym powtórzeniu się w Dniepropietrowsku (od 2016 roku miasto Dnipro) scenariusza z Doniecka czy Ługańska. Następnie te grupy zostały przeformatowane w zbrojne bataliony „Dnipro”, „Donbas" oraz „Ajdar" i zaangażowane w wojenne działania na wschodzie Ukrainy przeciwko separatystom i regularnym oddziałom rosyjskiego wojska. 
w zakresie walki z oligarchicznym systemem w państwie? Odpowiedź na to pytanie pozwoli nie tylko zweryfikować, co udało się zrealizować, lecz umożliwi również dokonanie oceny kondycji demokracji we współczesnym państwie ukraińskim. Jest ona bowiem przez ukraińskich ekspertów politycznych określana mianem „demokracji imitacyjnej”, co wynika właśnie z powiązania władzy z oligarchami, którzy wywierają znaczący wpływ na procesy decyzyjne $\mathrm{w}$ państwie ${ }^{3}$. Dokonanie zmian $\mathrm{w}$ tym aspekcie jest priorytetem, dlatego ukraińskie społeczeństwo, pragnące uzdrowienia politycznego systemu, podczas wyborów z nadzieją przyjmuje i popiera obietnice walki z oligarchią. Celem niniejszego artykułu jest więc analiza procesu deoligarchizacji na Ukrainie, uwzględniająca okres po wydarzeniach rewolucji godności, która miała stanowić principio novi saeculi w kształtowaniu nowego, opierającego się na demokratycznych zasadach, ładu w państwie. Porównanie prezydentur Petra Poroszenki i Wołodymyra Zełenskiego pozwoli na wyprowadzenie wstępnych wniosków oraz przedstawienie domniemywanych scenariuszy naprawiania politycznego systemu, a także oraz demokracji w tym państwie. Autor, dążąc do zobiektywizowania procesu badawczego, włącza w swoją narrację również opinie ukraińskich ekspertów politycznych reprezentujących różne ośrodki badawcze ${ }^{4}$. W kolejnej części artykułu zostaną przedstawione sposoby walki z oligarchią stosowane przez Petra Poroszenkę oraz Wołodymyra Zełenskiego.

3 Opinia Jewhena Mahdy - jednego z czołowych ukraińskich politologów, dyrektora Instytutu Światowej Polityki w Kijowie - wyrażona w wywiadzie przeprowadzonym przez autora 13 maja 2021 roku.

4 Autor w niniejszym artykule przedstawia opinie Jewhena Mahdy, dyrektora Instytutu Światowej Polityki w Kijowie; Ihora Semywołosa, dyrektora wykonawczego Ośrodka Studiów Bliskowschodnich; oraz Stanisława Żelichowskiego, ukraińskiego politologa z Akademii Dyplomatycznej Ukrainy im. Henadija Udowenki funkcjonującego przy Ministerstwie Spraw Zagranicznych. Opinie ekspertów stanowią części wywiadów przeprowadzonych przez autora w okresie między 25 kwietnia a 15 maja 2021 roku w ramach realizacji czynności badawczych. 


\section{DEOLIGARCHIZACJA NA UKRAINIE PO REWOLUCJI GODNOŚCI}

Rewolucja godności miała doprowadzić do radykalnych zmian na ukraińskiej scenie politycznej. Ucieczka do Rosji Wiktora Janukowicza i osób związanych z jego otoczeniem wskazywała na korzystny dla państwa efekt. Dążono przede wszystkim do zlikwidowania destrukcyjnej prorosyjskiej retoryki, która obowiązywała na Ukrainie od czasów prezydentury Leonida Kuczmy. W tym kontekście nawet pomarańczowa rewolucja z przełomu 2004/2005 roku nie przyniosła zamierzonych rezultatów, bowiem mimo narodowego zrywu i przywrócenia nacjonalistycznej narracji ${ }^{5}$, rzeczywiste osiągnięcia związane z reformowaniem państwa miały fasadowy charakter. Rewolucja godności miała zdecydowanie szerszy zakres, bowiem należało przeprowadzić nie tylko zmianę elit rządzących, lecz przede wszystkim zmienić nastawienie społeczeństwa do instytucji państwa jako gwaranta rozwoju i bezpieczeństwa, gdyż zostało ono znacząco osłabione, zwłaszcza za czasów prezydentury Wiktora Janukowicza.

\section{PETRO POROSZENKO}

Petro Poroszenko, doskonale zdający sprawę z oczekiwań ukraińskiego społeczeństwa po rewolucji, zapowiadał radykalną walkę z oligarchią jako źródłem politycznej korupcji i gospodarczego bandytyzmu w państwie (Samofalov et al., 2015). Stanowiło to jeden z najważniejszych punktów w jego programie wyborczym, który przyczynił się do zdecydowanej wygranej w wyborach prezydenckich tego polityka już w I turze (Kostiuk et al., 2015) ${ }^{6}$.

5 Jednym z przejawów tego rodzaju polityki Kijowa było nadanie przez Wiktora Juszczenkę tytułu Bohatera Ukrainy byłemu przywódcy Organizacji Ukraińskich Nacjonalistów Stepanowi Banderze. Więcej na ten temat w artykule Grzegorza Mazura Rozważania nad kwestia tradycji skrajnie nacjonalistycznych ruchów w polityce historycznej współczesnej Ukrainy. Zarys problematyki. Studia z dziejów Europy Wschodniej i Państw Bałtyckich, nr 7 (2016), s. 173-239.

6 Petro Poroszenko zwyciężył w 1. turze przedterminowych wyborach prezydenta Ukrainy, które odbyły się 25 maja 2014 roku, zdobywając 54,70\% 
Kilka tygodni przed dniem rozstrzygnięcia wyborczej batalii Petro Poroszenko spotkał się w Wiedniu z oligarchami Dmytrem Firtaszem i Serhijem Lowoczkinym, jak również z Witalijem Kliczko, który również wystartował w wyborach prezydenckich. Zawarto wówczas niezwykle korzystne dla Petra Poroszenki porozumienie, zgodnie z którym dwójka oligarchów wyrażała swoje poparcie dla jego kandydatury, a Witaj Kliczko obiecywał rezygnację z udziału w wyborach i swoje poparcie kandydaturze Petra Poroszenki (Theise et al. 2017). Ten układ, nazwany przez ukraińskich analityków politycznych „wiedeńskim sojuszem”, po raz kolejny podkreślił znaczenie oraz wpływy oligarchów na życie polityczne w państwie ${ }^{7}$.

Mimo obietnic uzdrowienia systemu politycznego - złożonych na Majdanie obywatelom przez Petra Poroszenkę - ukraińska scena polityczna po wyborach 2014 roku została ponownie podzielona na dwa ośrodki wpływów. Z jednej strony uplasował się obóz Petra Poroszenki, a z drugiej - Arsenija Jaceniuka, który mimo wielu głosów społecznej dezaprobaty znalazł się na stanowisku premiera. Z tym pierwszym ośrodkiem, co nie stanowiło zaskoczenia, związani byli między innymi Dmytro Firtasz i Serhij Lowoczkin, z drugim Ihor Kołomojski i Rinat Achmetow (Konończuk, 2016). Ogólny zarys porewolucyjnych układów na ukraińskiej scenie politycznej jednoznacznie wskazywał, że stary system powiązań między władzą i dużym biznesem przetrwał. Oligarchowie uzyskali w tym rozrachunku polityczną protekcję ze strony władzy na realizację swoich partykularnych interesów, a władza - finansowe oraz medialne zaplecze na realizację swoich projektów politycznych (Seddom et al. 2015).

Układ ten nie przetrwał zbyt długo, bowiem Petro Poroszenko zaczął podążać w kierunku umocnienia własnej pozycji na ukraińskiej scenie politycznej, uderzając w interesy oligarchów, ze strony których odczuwał bezpośrednie zagrożenie dla swoich interesów. Do tej grupy należy między innymi Dmytro Firtasz, który pozostawał

głosów. Na drugim miejscu uplasowała się Julia Tymoszenko z wynikiem 12,81\% głosów.

7 Opinia Ihora Semywołosa, dyrektora wykonawczego Ośrodka Studiów Bliskowschodnich, wyrażona w wywiadzie przeprowadzonym przez autora 25 kwietnia 2021 roku. 
w areszcie domowym w Wiedniu ${ }^{8}$, czy też Ihor Kołomojski, w którym Petro Poroszenko upatrywał swojego największego rywala (Romanyuk et al., 2019). Jednym z kroków podjętych przez ówczesnego prezydenta $\mathrm{w}$ zakresie walki z Ihorem Kołomojskim była nacjonalizacja Prywat Banku, którego właścicielem był oligarcha. Ten krok w postepowaniu prezydenta uzasadniano dążeniem do zapewnienia stabilności systemu finansowego, bowiem problemy Prywat Banku kumulowały się przez lata, a jego pozycja w państwie była na tyle znacząca, że najmniejsze zawahanie w funkcjonowaniu tej instytucji mogłoby doprowadzić do znaczącego kryzysu w sektorze finansów publicznych (Kuryshko et al., 2016). Nacjonalizacja Prywat Banku stanowiła znaczący cios dla Ihora Kołomojskiego, co doprowadziło do niewypowiedzianej, ukrytej, trwającej po dziś dzień wojny między nim a Petrem Poroszenką.

Walka z oligarchami miała przejawiać nie tylko poprzez nacjonalizację przedsiębiorstw, lecz przede wszystkim poprzez demonopolizację, stanowiącą jedno z zasadniczych żądań protestujących podczas rewolucji godności. Najbardziej zmonopolizowanymi sektorami gospodarki państwa są energetyka oraz sektor przesyłowy. Jednak, jak zaznacza Stanisław Żelichowski, ówczesny prezydent w trakcie swojej kadencji nie podjął decyzji o demonopolizacji tych sektorów, tłumacząc to zagrożeniem utraty zagranicznych inwestorów, przez których tego rodzaju fluktuacje nie są mile widziane9. Okres prezydentury Petra Poroszenki to również czas licznych skandali korupcyjnych, które nadwerężyły pozycję tego polityka w ukraińskim społeczeństwie. Jedną z takich afer, która obiła się głośnym echem również za

8 Dmytro Firtasz został zatrzymany w marcu 2014 roku w Wiedniu. Nakaz jego aresztowania został wydany przez Sąd Okręgowy w stanie Illinois latem 2013 roku. Dmytro Firtasz został oskarżony w Stanach Zjednoczonych o działania korupcyjne polegające na przekupywaniu indyjskich urzędników w celu uzyskania zezwoleń na eksploatację złóż tytanu w Indiach. Oligarcha został zwolniony za kaucją w wysokości 125 milionów euro i przebywa w areszcie domowym w swojej wiedeńskiej rezydencji. Przypuszcza się, że środki na kaucję pochodziły z Rosji. Stany Zjednoczone domagają się ekstradycji Firtasza z Austrii.

9 Opinia Stanisława Żelichowskiego, ukraińskiego politologa z Akademii Dyplomatycznej Ukrainy im. Henadija Udowenki funkcjonującej przy Ministerstwie Spraw Zagranicznych, wyrażona w wywiadzie przeprowadzonym przez autora 15 maja 2021 roku. 
granicami państwa, była rezygnacja ze stanowiska ministra rozwoju gospodarczego i handlu Ukrainy Aivarasa Abromavičiusa. Oskarżył on obóz prezydencki, a w szczególności bliskiego współpracownika Petra Poroszenki Ihora Kononenkę o polityczną korupcję i działanie na szkodę państwa ukraińskiego (Zanuda et al., 2016).

Petro Poroszenko, mimo swoich głośnych postulatów walki z oligarchia, aby ratować swoją pozycję sięgnął po pomoc najbogatszej osoby w państwie Rinata Achmetowa, który pozostawał w cieniu konfrontacji na linii prezydent-oligarchowie. Warunkiem umowy było dokonanie zmiany na stanowisku premiera, bowiem miał nim zostać Wołodymyr Hrojsman, bliski współpracownik Rinata Achmetowa. Poparcie najbogatszego oligarchy, a przede wszystkim jego medialnego zaplecza, zwiększało szanse na wygraną w kolejnych wyborach. Było to niezwykle ważne dla Petra Poroszenki, gdyż oligarchowie, którzy wspierali go przed wyborami w 2014 roku - między innymi Dmytro Firtasz oraz Serhii Lowoczkin - zjednoczyli się przeciwko niemu.

Pozycja ówczesnego prezydenta została również znacząco nadszarpnięta wskutek ujawnienia przez dziennikarzy śledczych z kanału 1+1 tzw. "formuły Rotterdam +". Dotyczyła ona ustalenia ceny węgla importowanego na terytorium Ukrainy według wzoru uwzględniającego cenę rynkową węgla importowanego do portów Amsterdam-Rotterdam-Antwerpia z ostatnich 12 miesięcy, biorąc pod uwagę również koszty dostawy. Nie budziłoby to żadnych wątpliwości, gdyby nie fakt, że do Niderlandów był wwożony ukraiński węgiel, a następnie, ze sztucznie podniesioną cena, wracał na Ukrainę, wzbogacając tym samym przedsiębiorstwa energetyczne należące do ukraińskich oligarchów, przede wszystkim Rinata Achmetowa (Peretyaka et al., 2017). Wymownym w tej sprawie było to, że nikt zasadniczo nie poniósł odpowiedzialności za udział w imporcie węgla z formułą Rotterdam +, co niezwykle oburzyło opinię publiczną na Ukrainie.

Prezydencka kampania, z którą Petro Poroszenko wystartował $\mathrm{w}$ kolejnych wyborach prezydenckich, znacząco różniła się od tej z 2014 roku, zwłaszcza w kontekście walki z oligarchią. Zaskakujące jest to, że kwestia deoligarchizacji w ogóle zniknęła z programu wyborczego tego polityka. Oleh Medwediew, rzecznik sztabu wyborczego Petra Poroszenki, tłumaczył, że termin „deoligarchizacja” jest 
postrzegany przez społeczeństwo w sposób kontrowersyjny (Radio Svoboda et al., 2019). Miało to jednak swoje pragmatyczne podłoże, gdyż Petro Poroszenko doskonale zdawał sprawę, że nie może podczas kampanii wyborczej narażać się tym oligarchom, którzy nadal pozostawali z nim w przyjaźni. Oznaczało to jedno - system powiązań między władzą a oligarchia, mający na celu jedynie zapewnienie korzyści zaangażowanym stronom, nadal przetrwał.

\section{WOŁODYMYR ZEŁENSKI}

Wołodymyr Zełenski wystartował $\mathrm{w}$ wyborach prezydenckich w 2019 roku niespodziewanie dla większości społeczeństwa. Kojarzony był przede wszystkim jako twórca oraz aktywny uczestnik komediowych spektakli "Studio 95 Kwartał” oraz jako aktor w satyrycznym serialu Stuga narodu, gdzie odgrywał rolę Wasyla Gołoborodka - prezydenta państwa. Społeczeństwo ukraińskie z entuzjazmem przyjęło wiadomość o starcie Wołodymyra Zełenskiego w realnych wyborach prezydenckich. Jednak twierdzono wówczas, iż decyzja ta jest „wielkim żartem” Ihora Kołomojskiego, który był partnerem biznesowym Wołodymyra Zełenskiego, bowiem produkcja „Studio 95 Kwartał” ukazywała się na kanałach telewizyjnych oligarchy. Ponadto Ihor Kołomojski aktywnie wspierał kandydaturę Wołodymyra Zełenskiego, udostępniając mu swoje kanały informacyjne oraz zapewniając wsparcie logistyczne. Istniało przekonanie, że start aktora-komika $\mathrm{w}$ wyborach prezydenckich jest jedynie odwetem na Petrze Poroszence za nacjonalizację Prywat Banku.

Ukraińcy polubili Wołodymyra Zełenskiego jako aktora, a w 2019 roku byli ciekawi poznania Wołodymyra Zełenskiego jako polityka. Wskazuje na to wynik II tury wyborów, podczas której Wołodymyr Zełenski uzyskał aż 73\% głosów, w zdecydowany sposób pokonując Petra Poroszenkę.

W jego programie wyborczym nie mogło zabraknąć punktu o deoligarchizacji (Ze! Komanda et al., 2019). Miała ona przybrać systemowy charakter, opierający się na legislacyjnych instrumentach regulujących relacje przedstawicieli władzy z oligarchami. W maju 2020 roku Rada Najwyższa poparła ustawę „O naprawianiu niektórych mechanizmów regulacji działalności banków”. Celem tego aktu 
prawnego było uzdrowienie systemu finansowego poprzez zapobieganie upadłości banków. Miało to również bezpośredni związek ze sprawą Prywat Banku Ihora Kołomojskiego, bowiem wejście w życie tej ustawy blokowało możliwość powrotu tej finansowej instytucji w ręce oligarchy, gdyż przed nacjonalizacją bank ten miał status „niepewnego" (BBC News Ukraine et al., 2020). Ponadto Wołodymyr Zełenski przyczynił się do „wyłączenia” z ukraińskiej sfery medialnej kanałów informacyjnych 112, ZIK oraz NewsOne, które były uważane za tubę rosyjskiej propagandy na Ukrainie. Ich właścicielem de jure był Taras Kozak, lecz de facto - Wiktor Medwedczuk, oligarcha nazywany jednocześnie „człowiekiem Władimira Putina na Ukrainie" (Savchenko et al., 2021).

Tym niemniej walka z oligarchią wymagała bardziej kompleksowego podejścia. Wołodymyr Zełenski, mimo wielu głosów krytyki ze strony środowisk politycznych znajdujących się pod oligarchicznymi wpływami, 2 czerwca 2021 roku złożył do Rady Najwyższej projekt ustawy o deoligarchizacji. Zakładano,że ustawa ta powinna stanowić tło dla formułowania innych prezydenckich projektów ustaw, które będą regulowały kwestie demonopolizacji rynku oraz kwestie dotyczące funkcjonowania przestrzeni informacyjnej w państwie.

Projekt ustawy zakłada między innymi kryteria, które będą wskazywały, czy dana osoba jest oligarchą, czy też nie. Należą do nich takie aspekty, jak: aktywny udział w politycznym życiu; znaczący wpływ (między innymi poprzez posiadanie) na środki masowego przekazu; zajmowanie pozycji monopolisty w określonym sektorze gospodarki (utrzymywanie tej pozycji przez rok na tym samym poziomie albo jej wzmocnienie) oraz posiadanie aktywów finansowych w wysokości ponad $1 \mathrm{mln}$ socjalnych minimów (biorąc pod uwagę kryterium minimum socjalnego na Ukrainie w 2021 roku), co w przeliczeniu wynosi około 80 mln dolarów amerykańskich (BBC News Ukraine et al., 2021). Status oligarchy otrzymuje osoba, która spełnia łącznie trzy z przywołanych powyżej kryteriów. Proces wyznaczania statusu oligarchy leży przede wszystkim w kompetencji Rady Bezpieczeństwa Narodowego i Obrony $(\mathrm{RNBO})^{10}$. Po uznaniu przez

10 RNBO - Rada Bezpieczeństwa Narodowego i Obrony jest organem doradczym oraz koordynacyjnym prezydenta Ukrainy, którą powołuje i odwołuje sam prezydent. 
RNBO danej osoby za oligarchę, wpisuje się ją do rejestru oligarchów. Skutkiem trafienia do tego spisu będzie zakaz finansowania partii politycznych oraz zakaz nabywania wielkich przedsiębiorstw, aby $\mathrm{w}$ ten sposób zapobiec monopolizacji rynku. Ponadto osoby wniesione do rejestru oligarchów będą musiały składać sprawozdania dotyczące kontaktów z politykami oraz pracownikami służby publicznej. W ten sposób ustawa będzie zapobiegała między innymi politycznej korupcji szeroko rozpowszechnionej wśród państwowych oficjeli.

Tym niemniej przyjęcie projektu ustawy deoligarchizacyjnej spotkało się z krytyką ze strony zarówno środowisk eksperckich, jak i niektórych oligarchów. Zarzucano bowiem, że projekt ustawy w sposób nieprecyzyjny definiuje kryteria określające osobę oligarchy. Zaskakującym jest to, iż zapis ustawy jest na tyle nieprecyzyjny, że Rinat Achmetow, uważany za najbogatszego oligarchę na Ukrainie, może znaleźć się poza rejestrem oligarchów. Jest to możliwe w sytuacji przekazania przez Rinata Achmetowa środków masowego przekazu innej osobie, co de jure będzie świadczyło jedynie o spełnieniu dwóch z czterech kryteriów wskazanych w ustawie. Dokonując szczegółowej analizy tego dokumentu, można wywnioskować również, iż określenie, czy ktoś jest oligarchą, czy nie, w dużym stopniu będzie zależało od RNBO, a tym samym od osoby prezydenta. Wskazuje to na subiektywny charakter procesu deoligarchizacji, bowiem istnieje zagrożenie, że Wołodymyr Zełenski tworzy jedynie instrument politycznej walki, mający zapewnić mu względną stabilność pozycji jako głowy państwa. Petro Poroszenko podkreśla, że ustawa o deoligarchizacji w takim brzmieniu, jak ją zaproponował Wołodymyr Zełenski, jest niczym innym, jak próbą uderzenia w jego osobę oraz pozycję w państwie jako jednego z liderów opozycji (Kramar et al., 2021).

Przyjęcie tej ustawy będzie stanowiło precedens, bowiem dotychczas nikt nie odważył się w ten sposób walczyć przeciwko wpływom oligarchów w państwie. Wątpliwości budzi jednak pytanie, czy ustawa ta zostanie przyjęta przez Radę Najwyższą w takim kształcie, jak złożył ją Wołodymyr Zełenski, bowiem w parlamencie obecnej kadencji znajduje się prawie siedemdziesięciu parlamentarzystów będących pod wpływem Ihora Kołomojskiego i stu tworzących tzw. "grupę Rinata" (od imienia najbogatszego ukraińskiego oligarchy 
Rinata Achmetowa) (Українська правда et al., 2021). Przyjęcie tej ustawy w parlamencie będzie oznaczało początek nowego etapu $\mathrm{w}$ walce $\mathrm{z}$ oligarchią. Tym niemniej już pierwsze czytanie projektu wskazało, że batalia parlamentarna o przyjęcie ustawy deoligarchizacyjnej dopiero się zaczyna. Do tekstu projektu wskazano aż 1271 poprawek, co więcej, skierowano go również do rozpatrzenia przez Komisję Wenecką pod zarzutem rażącego naruszenia Konstytucji Ukrainy, a przede wszystkim naruszenia podstawowych praw i wolności obywateli (Ekonomichna Pravda et al., 2021). Warto zatem nadal śledzić postępowanie legislacyjne dotyczące ustawy o deoligarchizacji, gdyż jej przyjęcie z pewnością w znaczący sposób wpłynie na funkcjonowanie państwa ukraińskiego w przyszłości.

\section{KONKLUZJE}

Lucan Way oraz Steven Levitsky, badając systemy polityczne państw byłego Związku Radzieckiego stwierdzili, że reżim panujący na Ukrainie po 1991 roku można określić mianem „konkurencyjnego autorytaryzmu" (Way, Levitsky, 2010). Oznacza to, iż system władzy w tym państwie sprowadza się do formuły istnienia silnego prezydenta, w otoczeniu którego odbywa się konkurencyjna rywalizacja o wpływy między przedstawicielami oligarchicznego świata. Społeczeństwo w tym układzie służy jedynie jako instrument legitymizujący sposób zdobycia władzy poprzez zwycięstwo w demokratycznych wyborach.

Petro Poroszenko, będąc ",starym” "11 graczem na ukraińskiej scenie politycznej, doskonale wpisuje się w model zaprezentowany przez Lucana Waya oraz Stevena Levitskiego. Jego dążeniem po objęciu stanowiska głowy państwa była neutralizacja konkurencji ze strony innych oligarchów. Strategia Petra Poroszenki polegała na tym, aby nie szkodzić bardziej wpływowym od siebie. W praktyce oznaczało to, że ówczesny prezydent wcześniej czy później i tak zwróciłby się po pomoc do Rinata Achmetowa, bowiem ukryte wojny, które prowadził z Dmytrem Firtaszem, Serhijem Lowoczkinym czy też

11 Polityczne życie Petra Poroszenki zaczęło się w 1998 roku, gdy został wybrany do Rady Najwyższej z ramienia Socjaldemokratycznej Partii Ukrainy (z). 
Ihorem Kołomojskim, wymagały zawarcia koalicji zapewniającej jego finansową i polityczną stabilność w państwie.

Wołodymyr Zełenski, będąc tym „nowym”, który swoją polityczną karierę rozpoczął od startu w wyborach prezydenckich w 2019 roku, przyczynił się do zmiany dotychczasowego modelu demokracji oligarchicznej w państwie. Mimo wielu zarzutów dotyczących kontaktów z oligarchami, Wołodymyr Zełenski podejmuje konkretne kroki skierowane na ograniczenie wpływów oligarchów na procesy decyzyjne, czego potwierdzeniem jest między innymi wspomniana $\mathrm{w}$ niniejszym artykule ustawa o deoligarchizacji. Istotnym $\mathrm{w}$ tym kontekście jednak jest to, że Wołodymyr Zełenski przyszedł do polityki bez politycznego zaplecza w postaci sprawdzonego i kompetentnego zespołu. Co więcej, nadal zmaga się z zarzutem, który pochodził jeszcze z czasu wyborów, iż jest jedynie pionkiem na ukraińskiej scenie politycznej, którym zza kulis kieruje Ihor Kołomojski. Rzecz jasna, zarówno prezydent, jak i oligarcha, zaprzeczają tej współpracy.

Reasumując należy zaznaczyć, że wraz z przyjściem Wołodymyra Zełenskiego do ukraińskiej polityki nastąpiła redefinicja dotychczasowych norm funkcjonowania państwa. Zaczął się kształtować nowy, bardziej demokratyczny model, w którym obietnice składane podczas wyborów są rzeczywiście realizowane. Można jedynie domniemywać, w jakim kierunku będzie podążało państwo ukraińskie w przyszłości. Na podstawie przywołanych w niniejszym artykule danych, uzasadnione jest wskazanie dwóch scenariuszy rozwoju sytuacji. Pierwszy - optymistyczny: Wołodymyr Zełenski pozostanie niezależnym politykiem, realizującym swoje obietnice wyborcze skierowane na naprawę demokratycznego systemu w państwie poprzez zminimalizowanie oligarchicznych wpływów. Drugi - pesymistyczny: Wołodymyr Zełenski będzie realizował partykularne interesy określonej grupy oligarchów, tym samym utrzymując model oligarchicznej demokracji na Ukrainie. Bardziej prawdopodobny wydaje się ten pierwszy scenariusz. Jednak weryfikacja tego nastąpi dopiero po upływie okresu prezydentury Wołodymyra Zełenskiego. Będzie to stanowiło doskonały pretekst do dalszych badań nad kondycją ukraińskiej demokracji, w kontekście transformacji modelu kooperacji władzy i oligarchii, według którego dotychczas były dyktowane warunki życia politycznego w państwie. 


\section{Bibliografia}

BBC News Ukraine. (2021). "Antykolomoys'kyy" zakon: Verhouna Rada progolosuvala za nepovernennya "Prywat Banku” Kolomoys' komu [“Anti-Kolomoisky" Law: The Verkhovna Rada Voted For Non-Return of "PrivatBank" to Kolomoisky]. https://www.bbc.com/ukrainian/ news-52095009 (dostęp: 15.05.2021).

BBC News Ukraine. (2021). Zakon pro deoligarhizaciyu v Radi: yak Zelens'kyy "minusuvatyme" Oligarhiv [The Law on De-Oligarchization in the Rada: How Zelensky Will „Minus” the Oligarchs]. https://www.bbc. com/ukrainian/news-57342328 (dostęp: 2.06.2021).

Biryukov, A. (2001). Bankruptcy and Legislation Reform in Ukraine. Review of Central and East European Law, 4, 581-600.

Ekonomichna Pravda. (2021). Komitet rekomenduvav zakonoproyekt pro,,oligarhiv" do druhoho chytannya: shcho zminylosya [The Committee Recommended the Bill on "Oligarchs" Before the Second Reading: What Has Changed. https://www.epravda.com.ua/news/2021/09/17/677933/ (dostęp: 18.09.2021).

Holovko, V. (2012). Ukayins'ki finansovo-promyslovi hrupy v modernizaciynyh procesach 1991-2009 [Ukrainian Financial-Industrial Groups in the Modernization Processes of 1991-2009]. Kyiv: Institute of History of Ukraine, National Academy of Sciences of Ukraine.

Konończuk, W. (2016). Fundament systemu. Starzy i nowi oligarchowie na Ukrainie. Ośrodek Studiów Wschodnich. Punkt Widzenia, 59.

Kostiuk, B. (2015). Ukraina bez oligarhiv: jakshcho mozhlyvo, to yak? [Ukraine without oligarchs: if possible, how?]. Radio Svoboda. https://www. radiosvoboda.org/a/26928060.html (dostęp: 12.09.2021).

Kramar, O. (2021). U Poroshenka kazhut', shcho zakonoproyekt pro oligarhiv spryamovanyy proty nyogo. Zelens'kogo zvynuvachuyut' u zahoplenni vla$d y$ [Poroshenko Says That the Bill on Oligarchs Is Directed Against Him. Zelensky Is Accused of Seizing Power]. Hromadske.ua. https:// hromadske.ua/posts/u-poroshenka-kazhut-sho-zakonoproyekt-pro-oligarhiv-spryamovanij-proti-nogo-zelenskogo-zvinuvachuyut-u-zahoplenni-vladi (dostęp: 12.09.2021).

Kuryshko, D. (2016). Nacionalizaciya PryvatBanku u pytannyah i vidpovidyah [Nationalization of PrivatBank in questions and answers]. BBC News. Ukraine. https://www.bbc.com/ukrainian/news-38370169 (dostęp: 4.05.2021).

Larcev, V., Klyuchnikov, G. (2001). Ukrayins'ka pryvatyzaciya u spohadah i rozdumah [Ukrainian Privatization in Memories and Reflections]. Kyiv: Poligraf_Inform. 
Matuszak, S. (2012). Demokracja oligarchiczna. Wptyw grup biznesowych na ukraińska politykę. Ośrodek Studiów Wschodnich. Prace, 42.

Peretyaka, O. (2017). Nepohytnyy "Rotterdam +": yak "elita" poshyla u durni vsih ukrayinciv [Unwavering "Rotterdam +": How the "Elite" Fooled All Ukrainians]. Ekonomichna Pravda. https://www.epravda.com. ua/publications/2017/08/14/ (dostęp: 22.04.2021).

Radio Svoboda. (2019). U Poroshenka poyasnyly, chomu v yoho prohrami nemaye "deoligarhizaciyi" [Poroshenko Explained Why There Was No "De-Oligarchization" in His Program]. https://www.radiosvoboda. org/a/news-schemes-poroshenko (dostęp: 25.04.2021).

Romanyuk, R. (2019). Oligarhiv bahato - prezydent odyn. Poroshenko proty Kolomoys'koho, Firtasha i Lyovochkina [There Are Many Oligarchs - One President. Poroshenko Against Kolomoisky, Firtash and Levochkin]. Ukrainian Pravda. https://www.pravda.com.ua/articles/2019/03/19/7209543/ (dostęp: 21.04.2021).

Samofalov, A. (2015). Operaciya "deoligarhizaciya". Yak Poroshenko vykonav nayhuchnishu obicyanku 2015 [Operation "De-oligarchization". How Poroshenko Fulfilled the Loudest Promise of 2015]. Ukrainian Pravda. https://www.pravda.com.ua/articles/2015/12/24/7093584/ (dostęp: 17.04.2021).

Savchenko, H. (2021). Blokada "kanaliv Medvedchuka”. Zahyst Ukrainy chy nastup na svobodu slova [Blockade of Medvedchuk's Channels. Defense of Ukraine or Attack on Freedom of Speech]. BBC News Ukraine. https://www.bbc.com/ukrainian/news-55922369 (dostęp: 15.04.2021).

Seddom, M. (2015). Washington's Man in Ukraine Cannot Stop His Country's Corrupt Cronies. BuzzNews. https://www.buzzfeed.com/maxseddon/ washingtons-man-in-ukraine-cant-stop-his-countrys-corrupt (dostęp: 12.04.2021).

The Economist Intelligence Unit (2021). Democracy Index 2020: In sickness and in health? https://www.eiu.com/n/campaigns/democracy-index-2020/ (dostęp: 12.04.2021).

Theise, E. (2017). Ukrainischer Oligarch beschert Wien Auslieferungskrimi. Deutsche Welle. https://www.dw.com/de/ukrainischer-oligarch-beschert-wien-auslieferungskrimi/a-37662722 (dostęp: 12.04.2021).

Ukrainian Pravda. (2021). Mayzhe 70 nardepiv pracyuyut' na Kolomojs'koho, shche 100 na Ahmetova - Bihus.Info [Almost 70 People's Deputies Work for Kolomoisky, Another 100 for Akhmetov - Bihus.Info]. https:// www.pravda.com.ua/news/2021/01/11/7279593/ (dostęp: 7.05.2021).

Way, L., Levitsky, S. (2010). Competitive Authoritarianism: Hybrid Regimes after the Cold War.. New York: Cambridge University Press.

Zanuda, A. (2016). Vidstavka Abromavychusa: ne dilom, a slovom? [Abromavicius' Resignation: Not In Deed, But In Word?]. BBC News Ukraine. 
https://www.bbc.com/ukrainian/business/2016/02/160203_abromavichus_resignation_economy_az (dostęp: 25.04.2021).

Ze! Komanda. (2019). Peredvyborcha programa kandydata na post Prezydenta Ukrayiny Volodymyra Zelens'kogo [Election Program of the Candidate for President of Ukraine Volodymyr Zelensky]. https://program. ze2019.com/ (dostęp: 12.09.2021).

\section{Copyright and License}

This article is published under the terms of the Creative Commons Attribution - NoDerivs (CC BY- ND 4.0) License http://creativecommons.org/licenses/by-nd/4.0/ 